\title{
ULAMA IN INDONESIAN URBAN SOCIETY: A View of Their Role and Position in the Change of Age
}

\author{
Muhammad Zainal Abidin \\ Universitas Islam Negeri Antasari Banjarmasin \\ e-mail:mzabidin@uin-antasari.acid
}

\begin{abstract}
The purpose of this study is to know how the changes of the social impact the role and the position of the ulama. Urban society is the real phenomena that happen for the coming of the industrialization era, or in another word that the urban society is the manifest of the industrial society. The writer sees the urban society phenomena as similar as the industrial society. This is a library research, which takes the source of study from the books and other literature related to the topic. The source of data is classified into two parts, the primary source, and the secondary one. As analysis technique, the writer uses the content analysis with the classification of sign-vehicles; which relies solely upon the judgments which theoretically, may range from perceptual discrimination to sheer guesses of analyst or group of analyst's judgment are regarded as the report of the scientific observer. Finally, it is found that in urban society after coming of the industrialization era. The role and the position of ulama have changed. The ulama in urban society is not the social category again, but the parameter of ulama in urban society is the intellectual one. The position of ulama is not like a kyai or a teacher anymore such as what happened in pre-industrial or semi-industrial, but the ulama become the partner of people.
\end{abstract}

\begin{abstract}
Abstrak: Paper ini bermaksud untuk mengetahui perubahan pada masyarakat terkait dengan peran dan posisi ulama pada masyarakat urban. Masyarakat urban merupakan fenomena nyata pada era industrialisasi. Dengakn kata lain, masyarakat urban merupakan manifestasi dari masyarakat industrial. Penulis melihat fenomena yang serupa antara masyarakat urban dengan masyarakat industri. Tulisan ini merupakan riset kepustakaan yang mengambil sumber data dari buku dan literatur lain yang relevan. Sumber data diklasifikasi menjadi dua bagian, sumber data primer dan sumber data sekunder. Untuk analisis digunakan analisis isi yang mengklasifikasi tanda baca, yang didasarkan pada penilaian secara teoritis, berkisar dari diskriminasi persepsi sampai dugaan analisis atau kelompok penilaian analisis yang dipandang sebagai laporan ilmiah. Temuan dari penelitian ini bahwa masyarakat urban muncul sesudah era industrialisasi. Peran dan posisi ulama telah berubah. Ulama pada masyarakat urban bukan lagi semata pada kategori sosial, tetapi parameter ulama pada masyarakat urban ada pada aspek intelektualitasnya. Posisi ulama bukan lagi Kyai atau guru sebagaimana fenomena pada masyarakat pra industri atau semi industri, tetapi ulama menjadi patner masyarakat.
\end{abstract}

Keywords: ulama; urban society; industrial society; change of age 


\section{A. Preface}

Indonesia is known as the country with the largest number of Muslims in the world. This large number is certainly not something that manifests suddenly. It is the da'wah efforts undertaken, especially by Islamic religious figures called 'ulamā'. Therefore, the religious scholars ('ulamō') have an important position in the life of the people of Indonesia until now. The position and role of ulama in Indonesia have experienced a fairly dynamic development from time to time. This is mainly due to the social, political and cultural changes that have taken place throughout Indonesia's history. These changes are not only about the position and social role of an ulama but also about the public perception of the various criteria that must be owned by someone who is considered 'ulamā'.

The dynamics of the existence of 'ulamä' in Indonesia can be seen from the use of the title attributed to him. The word 'ulamä' is taken from Arabic, as the plural of the word 'allim, meaning one who is knowledgeable. Since the science that originally developed in Islam is the science of religion, the 'ulamā' is usually the people who master the sciences of Islam. While in Indonesian, the word 'ulamā' is used as a singular, not plural. In terms of use, the word 'ulama' is usually used as a general term of identity, imposed on an Islamic religious leader. Because of its general nature, it is rarely heard that someone calls a 'Pak ulama' or 'Ibu ulama'. To call someone in particular, usually used another name according to the local culture. For example, the Javanese call scholars the 'kyai'.1 While in Banjar culture, there are titles such as 'master teacher', 'shaykh', 'datu', 'qadhi', 'mufti', 'mu'allim' and 'ustadz' or 'ustadzah.'2

Actually, in Moslem society, ulama as a religious scholar places a good position and role in guiding, educating and maintaining ummat. It happened for centuries since the emerging of Islam in Mecca $650 \mathrm{AD}$. The spread of Islam to

${ }^{1}$ Kyai and ulama as a term are two things that are not the same, although in Western literature often blurred and confused. According Horikoshi who did research on Kyai and Social Change mentioned that the difference between Kyai and Ulama is really very clear. Kyai is a charismatic leader in the field of religion, and has a strong influence on his followers. He is superior to commonly religious scholars (ulama) in applying the principles of ijtihadi. While ulama are religious officials. He holds religious affairs, which provide religious services on a regular basis. A scholar is more a teacher than a religious scholar, and in teaching shows more taqlid methods. His authority is limited to local religious affairs. See Hiroko Horikoshi, Kyai dan Perubahan Sosial, trans. Umar Basalim and Andi Muarly Sunrawa (Jakarta: Perhimpunan Pengembangan Pesantren dan Masyarakat, 1987), p. 1-3.

${ }_{2}^{2}$ Mujiburrahman, M. Zainal Abidin, and Rahmadi, Ulama Kharismatik di Tanah Banjar: Potret Guru Danau, Guru Bachiet, dan Guru Zuhdi (Yogyakarta: Kurnia Kalam Semesta, 2016), p. 2. 
whole the world, could not be released from the position and the role played by ulama through his sincere missionary that Islam became the respected religion among other religions and even got his golden age that dominated the world around 8th up to 13th $\mathrm{AD}^{3}$

Really, the existence of Islam posses a strong relationship and cannot be separated with ulama. If someone wishes to study about the condition of Moslem society, he must take this kind of group. Historically, there was no revolution happened in Moslem society without the participation of ulama. The good contemporary example from this is how the shape of Khomenei could lead the Iranian revolution of 1979.4

Then, the close relation between the ulama and Moslem society appeared a question, do the role and the position of ulama toward Moslem society always exist up to this present? This question is very important to appear for the world civilization today is very different from the earlier civilization. The human being civilization right now is the industrial civilization. The coming of this industrialization era appears a drastic change in human being civilization, particularly in the interaction among them. It also creates a new community called as an urban society.

Urban society is the opposite of rural society. For Milton John Yinger who assumes that all major religions in the world originated in the rural societies, the urban setting poses enormous problems to religious adherent and institutions. Contact with strangers often results in disenchantment, as strange environments in the cities disturb homogeneous ideals. The same contact also results in secularization, as contact with people from different religious persuasion demands adjustments in behavior. Religious tolerance can be the beginning of religious secularization. Another problem is the loosening of kinship ties. The close-knit community in rural surroundings is broken into pieces by the urban individualizing process. 5

${ }^{3}$ Muhammad Zainal Abidin, "Dinamika Perkembangan Ilmu Dalam Islam Serta Statusnya Dalam Perkembangan Peradaban Modern," Jurnal Ilmu Ushuluddin 11, no. 1 (2012): p. 21-42;; Muhammad Zainal Abidin, Paradigma Islam Dalam Pembangunan Ilmu Integralistik: Membaca Pemikiran Kuntowijoyo (Banjarmasin: IAIN Antasari Press, 2016), p. 30-34. 1984).

${ }^{4}$ Shaul Bakhash, The Reign of the Ayatollahs: Iran and the Islamic Revolution (Basic Books,

${ }^{5}$ Kuntowijoyo Kuntowijoyo, "Between Mosque and Market: The Muslim Community in Quiapo, Metro Manila," Studia Islamika 1, No. 3 (1994): p. 33-34, https://doi.org/10.15408/ sdi.v1i3.849.

JURNAL THEOLOGIA — Volume 28, Nomor 2, Desember 2017 
This process might entail a situation of anomie, in which former institutions have not been fully adopted. The birth of sectarian religions may be expected from urbanization process. In the case of Moslem, it is interesting to see whether such general expectations occur. Whatever if it is correlated with the relationship between society on one side and ulama in another side. This paper will study on the role and the position of ulama in urban society, which personifies the industrial society.

\section{B. The Discourse of Religiosity in Urban Society}

As the opposite of the rural community, urban society is often associated with the people who live in the city. In describing the city, Adam Kuper \& Jessica Kuper stated that the terms like city, urban, and urbanism refer to some variation phenomena incoherent with the difference of history and region. But, commonly, we can say the city as the certain place dwelled by many people. The study on urban society is not only to research the society life extensively but also the certain characteristics in their intern life. ${ }^{6}$

To know more about urban life, we may see the explanation of O'Conner on urbanism. At least there are two theories of urbanism according to O' Connor's concept. First, urbanism is as a community and secondly, urbanism is as a hierarchy. Urbanism as a community is that the city life flourishes according to community values with an intimate relationship amongst its member. Each person seems to know another so that wherever he goes or stays he does not feel isolated or excluded. Such a relation did not exclusively happen in "the elite's far-flung web" of family, friends or connection, but it reaches the ultimate idea that the city or even the nation is perceived as a single community. The common assumption is that everyone has a community just as he has a family. Therefore, any attempt to build community is basically "the need to have friends to get by". ${ }^{7}$

The other theory introduced by 0' Conner is urbanism as "hierarchy". Here he deals with "an urban status hierarchy" that ranks everyone community. Status hierarchy encompasses all aspect of their wealth, education, occupation, and ethnicity. ${ }^{8}$ The idiom of the hierarchy has changed from "indie" to hierarchy

${ }^{6}$ Adam Kuper, The Social Science Encyclopedia (Routledge, 2004), p. 110.

${ }^{7}$ Richard A O'Connor, A Theory of Indigenous Southeast Asian Urbanism (Singapore: Institute of Southeast Asian Studies (ISEAS), ASEAN Economic Research Unit, 1983), p. 5.

8Ibid., p. 10. 
of modernity. In the past, the indie idiom ranked superior status from king, court to the peasant. Then, modernity took over the social hierarchy, created bureaucracies and introduced a new education system. Therefore, everybody is ranked in the idiom of modernity. Modernity has eventually shaped organic social hierarchy because it differentiated people in term of the division of labor, academic, achievement and professionalism, which now determine where a person belongs. Moreover, modernity also gives the governing roles to educatedelates and bureaucrats, "not as a privilege but in the name of progress."

Finally, each of both theories has its own idiom, a coherent way of symbolizing what people think, say and do. Each idiom is embodied in institutions. These institutions are often the elite and urban center of society, but the idiom also reaches out to social and physical peripheries of society. And then, together as idiom and institution, community and hierarchy shape the city's meaning and give meaning to urban life.

In spite of the urban society is not similar to the industrial society, but it is often associated with it. Therefore, in this paper, the writer uses the same name to mention whether urban society or industrial society. Actually, the central problem of the study of urbanism is often lies in revealing certain characteristics constitute a peculiar way of life that can be identified as different from another lifestyle.

Every urban theory as A O' Conor argues creates an order. It defines some few known phenomena as significant and sees the rest as derivative or meaningless. In the case of urban theories, people in different places and different periods have their own 'folk' or 'indigenous' theories of the city. Since a theory creates a meaningful reality, an indigenous theory has its strength to retrieve a reality that must be understood to study a certain society. In short, O' Connor suggests studying an urban society through the reality within it. The phenomena which are defined significant "become significant because they shape the thoughts and deeds that shape the city." ${ }^{10}$

\footnotetext{
${ }^{9}$ Actually, as stated by Julia Day Howell and Martin van Bruinessen, that the social sciences for most of the twentieth century have been dominated by modernization theories (of both the left and right) according to which societies modernize by proliferating what Max Weber called 'rational' social forms. The rational-critical thought necessary to support the proper functioning of modern firms and other bureaucratic institutions, so the argument goes, would render religions less and less plausible and attractive.Martin van Bruinessen and Julia Day Howell, Sufism and The "modern" in Islam (London; New York; New York: I.B. Tauris, 2007), p. 5.
}

${ }^{10} \mathrm{O}^{\prime}$ Connor, $A$ Theory of Indigenous Southeast Asian Urbanism, p. 2. 
The process of urbanization had rendered ties of kinship less important and replaced them with the relationship of an instrumental, transitory and superficial character. Size, density, and heterogeneity characterize urban settlements, which in combination provide the basis for the complex division of labor and fundamental changes in nature of the social relations. ${ }^{11}$

The urbanization process may also affect social solidarity. As city dwellers composed of the whole mass of people, the massification process occurred within formerly intact communities does not emerge, the community will fall apart, which is the distinctive quality of urban society. Urban dwellers tend to lose the desire for a community, the desire for engagement and the desire for dependence..$^{12}$ This means that communal solidarity is replaced by the more rational type of solidarity, the kind that Durkheim called "organic solidarity". In this type of solidarity, people are organized through their interests, not through their common localities, culture or ethnic denominations. The lost of engagement is caused by the highly individualized urban setting, so that individual interests take first priority in social relationships. The feeling that there is some kind of interdependence diminished, replaced by feelings of self-interest and self-confidence, in terms of one should be his own before anything else. ${ }^{13}$

To understand the urban society can be acted through the understanding of industrial society, for one main characteristic of urban society is industrialization process. Industrialization according to Nurcholish Madjid in relation to the social change process, that is the social structure change from the social system preindustrial (agriculture, for instance) to the social-industrial system. Sometimes it can also be made parallel with the change from pre-modern society to the modern society or in popular term today the change from less developed country to the more developed country. ${ }^{14}$

From many kinds of social change theories, use some of them will help our discussion here. Tonnies contradicts between the relations of natural and organic of family, village, and town (gemeinschaft) with the artificial and isolated

${ }^{11}$ David Jary and Julia Jary, Collins Dictionary of Sociology (Glasgow, Scotland: Collins, 2012), 681, http://www.credoreference.com/book/collinssoc.

${ }^{12}$ Kuntowijoyo, “Between Mosque and Market," p. 34.

${ }^{13} \mathrm{Ibid}$.

${ }^{14}$ Nurcholish Majid, Islam: Kemodernan dan Keindonesiaan (Bandung: Mizan, 1998), p. 141. 
condition from urban life and industrial society (Gesellschaft), which the origin and natural relations among each other have ignored, and each person fights to get their fortune in competition.

More about the dichotomic theory of Tonnies, Parsons expands a theory known as pattern variables. Followed the theory of Parsons that the change of the traditional society to the industrial and modern society means the change from: 1) Affectivity to affective neutrality, that is the change from the behavior of action for pleasure to action with the delay of short aims to reach the long aims. The direct impact of this change in industrialization process is the shaping of needed capital, for the habits of saving and investing. Affective neutrality also signed the social relations of industrial society that have the contractual, impersonal and calculated quality. The need of immediate satisfaction will be found from through the traditional institutions, especially. 2) Particularism to universalism. The Industrialization tends to make disappear the particular exclusivity such as race and descent. Such particularism is inefficient and carries the ineffective energy. Indeed, the highest industrialized society either capitalist or socialist is the society that the stuck out of universal patterns and the open carrier for the talents and abilities. 3) The ascription to achievement. The achievement tends to be the basis for recruitment in full industrial society. The known example of ascription is nepotism that is the recruitment basis for kinship or blood relation. Nepotism is not parallel with the way of life of industrial and modern society. In another word, the change for industrialization is the change from prestige respect to the performance respect. 4) Diffuseness to specivity. It means the change from expanded and covered social relations to the relation, whom an actor limits, his attention to others in specific cases and not allowed any considerations. The example of a diffuse relation is the relation between father and son, while the specificity is the relationship between teacher and pupil in general or modern school. A father plays a role as a father toward his son in all situation, while a teacher just plays a role as teacher toward his pupil in a school or class situation or in related with the teaching and education situation. ${ }^{15}$

In the process of changing pattern of society, where was the place for religions? The presentation of modernization which was accompanied by urbanization, social mobility, secular education industrialization, will ultimately

\footnotetext{
${ }^{15}$ Ibid, p. 141.
} 
lead to a weakening of religion, magic, and superstition. ${ }^{16}$ Moreover, W. Rosto (1971) noted that in the transitional stage of development, modernization means the reduction in the role of religion or increase in secularism. But S. Snouck Hurgronje asserted that while modernization may affect religion, it remains an important element of social life. ${ }^{23}$

Robert N. Bellah made the same point: In conclusion, it seems worthwhile to stress that the process of secularization, which is part of what the transition from prescriptive to principle society is, does not mean that religion disappears. The function of religion in a principal society is different from that in prescriptive society but is not necessarily less important. Moreover, in the very process of transition religion may appear in many new guises. ${ }^{24}$

It is true that the social change forms in industrialization process influence the religiosity life negatively. For instance, in industrial society, the role of the second group will always replace the primary group. Including the secondary group is unit and work organization or production. While the primary group is family, tribe, religion and soon. The character of the second group is gesellschaft, while the primary one is gemeinschaft. In another hand, formality, zaklijkheid, and rationality shift more the intimacy, familiarity and affectivity. And in many cases, the role of parent, especially father as child socialization agent will less, replaced by the other social relation forms, for instance, the school and environment. This case, of course, has the influence in reducing the certain religiosity patterns. ${ }^{17}$

But, the religiosity reduction in industrial society caused by the more dominance of the science role. The science, either social or others is the conscious form of someone toward his milieu, either near or far, also the knowing or conquering over the existing problems. It caused at least the narrow of mystic or mystery field. In case, as explained before, the religious action is acted for the acknowledgment of the real supra-empiric or mystic and mystery. So, the industrialization process will impact the reduction of religion-magic that for some people is the expression of religiosity its self. For them, the industrialization reduced the religiosity.

${ }^{16}$ Fred R Von der Mehden, Religion and Modernization in Southeast Asia (Syracuse, N.Y.: Syracuse University Press, 1986), p. 10.

${ }^{17}$ Nurcholish Majid, Islam: Kemodernan dan Keindonesiaan, p. 148. 
While, for other people, even industrialization and modernization support and increase the religiosity. The pure and true religiosity has the dimension of intrinsic culture or cultural consummatory, that is the religious behavior seeing that the belief or faith as the goal of its self, and impacting the happiness for its intrinsic value. The religiosity in this dimension does not hope the utility out of its faith. Such religiosity dimension may be strengthened by the industrial social relation patterns because the instrumental value of thing has been prepared fully by the structure and industrial social pattern, so the religion becomes pure, means that I has no instrumental value.

So that the religiosity, which is not threatened by the industrialization and modernization process, even got the foundation of it, is out of magic, namely the naturalization of human behavior (physiomorphism of man). But, the other condition is the religiosity must be the basis for the existing concept of supraempiric that no changes to the empirical one. In another word, the source of belief and religious value must be understood by a human being and know its secrets. ${ }^{18}$

\section{The Concept of Ulama in Islam}

The Arabic word 'ulama' is the plural of 'alim, literally "man of knowledge". The opposite of 'ilm (knowledge) is jahl (ignorance). In the Qur'an both terms are frequently used in connection with knowledge of that which was revealed to the Prophet, or knowledge of God. Belief in God is 'ilm so that the 'alim is the believer; disbelief is jahl, so that the truly ignorant person is one who does not believe in God. By implication, one is an 'alim on account of knowledge of particular religious knowledge (the Qur'an, the Hadith, and Fiqh or Religious Law); and it has always been expected that the 'alim embody the qualities expected of one who believes in God and practices Islam. ${ }^{19}$

It is written in Encyclopedia of the Modern Middle East that the term ulama literally means those who possess knowledge (ilm), most particularly of Islam. The ulama emerged as the first interpreters of the Qur'an and transmitters of Hadith, the words, and deeds of the Prophet Muhammad. These scholars also

${ }^{18}$ Ibid., p. 149.

${ }^{19}$ John L Esposito, The Oxford Encyclopedia of the Modern Islamic World (New York [etc: Oxford University Press, 1995), p. 268-265.

JURNAL THEOLOGIA — Volume 28, Nomor 2, Desember 2017 
became the first to outline and elaborate the basic principles of Islamic Law (Shari'a). The ulama was central to Islamic education in the premodern Middle East. They regulated instruction at all levels and were instrumental in the process of training Islamic Scholars in madrasah, as residential colleges, which were established by the eleventh century. These medieval institutions developed a rigorous curriculum centered on instruction in the law and trained future jurists, theologians, and state functionaries. This system of higher education was the first in a series of successful attempts to link the ulama to political in the Islamic world. Members of ulama might also participate in Islamic mysticism as members, even leaders, of organized Sufi fraternities. ${ }^{20}$

In Indonesia, the term of ulama or 'ālim 'ulamā' which was first meant as the plural, then its meaning changes become the singular. The definition of ulama also becomes narrower, for it is meant as a person who has the religious knowledge in fiqh field. In Indonesia, ulama posses the same meaning with fuqahä'. Even in common meaning, the ulama is the fuqaha in worship case only.

However, the narrower of the meaning ulama since a long time ago up to this present, it does not lose his special characteristics, that is the knowledge of his which was taught in order to become khasssah (the feeling of fear or humble) toward Allah. So that, an ulama must be Moslem. Someone who just has religion (Islamic) knowledge like the Orientalists is not called ulama. ${ }^{21}$

There were some terms or nicknames for ulama in Indonesia. In Aceh it is called by Tengku; In West Sumatra called by Tuanku or Buya; in West Java called by Ajengan; in Middle or East Java called by Kiai; in Banjar region (South Borneo/Kalimantan), South Celebes/Sulawesi and Southeast Nusa usually called by Tuan Guru. While the ulama who led the țariqah called by Syekh. ${ }^{22}$

Actually, the term of ulama is coming from the word 'alim and being the plural of it. But in common definition today, ulama has been the singular. The 'alim means a person who has the knowledge, while the ulama refers to whom

${ }^{20}$ Reeva S Simon, Philip Mattar, and Richard W Bulliet, Encyclopedia of the Modern Middle East (New York [N.Y.]: Macmillan Library Reference USA: Simon \& Schuster Macmillan; Simon \& Schuster and Prentice Hall International, 1996), p. 1822-23.

${ }^{21}$ Mujiburrahman, Abidin, and Rahmadi, Ulama Kharismatik di Tanah Banjar, p. 2.

${ }^{22}$ Dewan Redaksi Ensiklopedi Islam, Ensiklopedi Islam (Jakarta: PT Ichtiar Baru Van Hoeve, 1994), p. 121. 
has the religious knowledge, especially in fiqh or Islamic law in spite of the fiqh scholar is more accurate called as faqih or fuqaha as its plural.

In al Qur'an the word ulama is found in two places. Firstly, at Surah Fatir, verse 28:

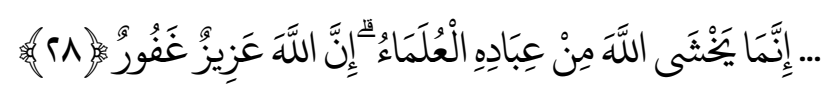

“... from among His servants, it is the learned who fear Allah. Allah is Mighty and Forgiving." 23

If this verse related to previously verse (verse 27), the meaning of ulama at this verse that is who has the knowledge of natural science or 'ilm kawniyyah. Secondly, at Sürah al-Shu'arä' verse 196 - 197:

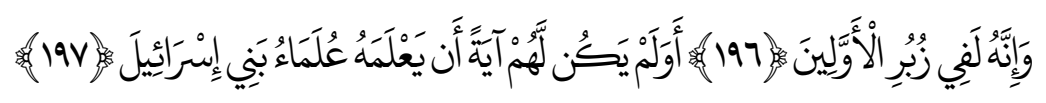

"It was (foretold) in the scriptures of the ancients. Is it not sufficient proof for them that the learned of the Children of Israel know it?"24

Here, the meaning of ulama is who has the religious knowledge.

From two these verses can be implied that the ulama is the man who posses the natural science and the religious knowledge and spends his knowledge for taking khāșsah (fear) him up to Allah.

There was also a prophet tradition (al-Hadith) transmitted by Buchori stating: "Indeed, the ulama is the heir of the prophets." In spite of Ibn Hajar al Asqalani, the hadith expert, hesitated the true of this hadith, but the soul of this hadith is coherent with the statement of al Qur'an at Surah Fatir verse 32:

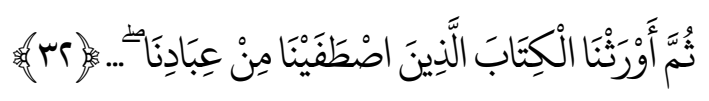

"Then We give the Book as an inheritance to those of our servants whom We have chosen..."25

${ }^{23}$ Mahmud Y Zayid, The Quran Dar: An English Translation of the Meaning of the Quran (Beirut: Dar Al-Choura, 1980), p. 321.

${ }^{24}$ Ibid., p. 273.

${ }^{25}$ Ibid., p. 321.

JURNAL THEOLOGIA — Volume 28, Nomor 2, Desember 2017 
When the Prophets have gone, so the duty of the prophets became the duty of ulama, that is tabligh or delivering, tabyin or explanation, tahkim or deciding of the case when there was a problem among human being, and as the uswah or the good example.

The ulama according to a prophet tradition is the heir of the prophets. Therefore, it can be referred that the duty of ulama is to continue the mission and the struggling of the prophets in delivering the God religion (din Alläh) toward a human being. The ulama is who dedicated his life to dig up the whole of Islamic teaching, to interpret and to systemize, and then to deliver it to society. Such process has been happening when the Rasulullah had gone and grew the branch of knowing known today as the Islamic traditional knowledge, especially 'ilm kalām (theology), fiqh (Islamic jurisprudence) and tasawwuf (mysticism). ${ }^{26}$

Historically, in the age of al Khulafä' al-Rāshidīn (the four of the first chalif), there is no distinction between the man who has the religious knowledge, the natural science, and leader of practical politic. Commonly, the companions of the Prophet have the religious of knowledge, the natural science, and immediately the actors of practical politic. The main companions in that time usually sat down together in judgment counsel called as ahl al-halli wa 'l-aqd. The companions then called as the 'ulamä'salaf. ${ }^{27}$

Just in Bani Umayyah government and after it, the term of ulama was more stressed for those who have the religious knowledge only. But, because of the classsification of religious knowledge, the term of ulama became narrower again. For instance, the fiqh experts were called as fuqahö', the hadith experts were called as muhaddithin, the kalām experts were called as mutakalliminn, the sufism experts were called as mutașawwif, and the interpretation experts were called as mufassir. While the people who have the natural science were not again called as ulama, but the expert in his field. The people like al Khawarizmi, al Biruni, and Ibn Hayyan were not called as ulama, but the natural expert (ahl al-kawniyyah). Those people may be called as ulama if they hold also the position as the owner of religious knowledge. The philosophy experts were not called as ulama. They

\footnotetext{
${ }^{26}$ Mujiburrahman, M. Zainal Abidin, and Rahmadi, "Ulama Banjar Kharismatik Masa Kini Di Kalimantan Selatan: Studi Terhadap Figur Guru Bachiet, Guru Danau, Dan Guru Zuhdi," Al Banjari 11, No. 2 (2012): p. 107-137.

${ }^{27}$ Dewan Redaksi Ensiklopedi Islam, Ensiklopedi Islam, p. 120.
} 
were called failasuf (philosopher) or hukamä' (the man who has wisdom). For example al Kindi, al Farabi, Ibn Rusyd, and al Ghazali.28 Exception, they have religious knowledge, they may be called as ulama. Ibn Rushd (Averroes) was known as a philosopher as well as the ulama of fiqh for his expert in fiqh issue. Al Ghazali has known besides the philosopher also as the ulama of fiqh, tasawwuf (sufism) and the expert of natural science. ${ }^{29}$

The ulama were often defined as a class, when in fact the socioeconomic status of their membership remained quite varied. Lawyers and judges were key members of the ulama; their legal skills were critical to the regulation of Islamic society in social and commercial matters such as wills, marriage, and trade. The ulama also included theologians, prayer leaders, and teachers, many of them who continued to participate in the economy as traders or artisans. Until the mid-nineteenth century, state bureaucracies in the Middle East employed members of the ulama as tax collectors, scribes, secretaries, and market inspectors. The ulama formed a cultural elite and retained the admiration and respect of the Muslim masses because the ulama, not the rulers, were perceived as the true guardians and interpreters of the Islamic faith. As long as the ulama remained independent of state control, they continued to represent a base of potential support or opposition to ruling elites. ${ }^{30}$

Conceptually, the ulama is different from the ministry class, the class who has the religious authority and could create the new rites, and they who has the exclusive right to lead the religious ceremonial. Actually, In Islam society, ulama can be a special class, but the class status has not the foundation of the quality of Islamic doctrine. Even, the ulama class may be loose in Islam society without the going of Islam society. His knowledge, his morality, and also his specific role to teach or to spread the Islamic teaching cause the authority of ulama. In the same time, an ulama is maybe a trader like al Ghazali who sell the carpet. An ulama is not the group who gets the salary, even though his main life source comes from his missionary activity.

${ }^{28}$ M. Zainal Abidin, "Positioning of Islamic Philosophy as the Basis of Establishment of Integralistic View of Science (Reposisi Filsafat Islam Sebagai Basis Pengembangan Ilmu Integralistik)," in IC-THUSI (Jakarta: Sadra International Institute, 2014), p. 1-20.

${ }^{29}$ Dewan Redaksi Ensiklopedi Islam, Ensiklopedi Islam, 121.

${ }^{30}$ Simon, Mattar, and Bulliet, Encyclopedia of the Modern Middle East. 
An ulama in fact, has the depth knowledge of Islamic teaching, even though he is maybe a soldier or a trader. By teaching the Islam, an ulama play the role as the class who participate to build up the value system, institution system, and the social behavior. This definition comes from the fact that mainly the quality of Islam is not only in the spiritual field, but also has the quality of the social and politics field. What is acted by ulama is not only to invite the people to come to the mosque but also to build the society up. ${ }^{31}$

There are some categories and non-formal conditions used by people to mention someone as ulama. However, those conditions and categories always change in the course of time. Prof. H. Aboebakar Atjeh mentioned four factors that cause someone called as ulama, namely: 1) his knowledge, 2) his piety, 3) his descendant, and 4) his total of pupils. Vredenbregt used the close criteria with Aboebakar Atjeh, that is 1) Descendent, 2) Religion Knowledge, 3) the Total of Pupils, and 4) the method of his public service. While Karel A. Sternberg added one factor again to someone who called as ulama, that is "revelation principle" or ulama as the mediator of revelation." 32

However, the ulama or kyai is not reached as alike the academic degree got from a certificate, but he was coming from the acknowledgment from the society. So that, there was no school may produce it directly. Talking about the ulama in the change of age, we have to set back to the 19th century as the beginning of the awakening of the Islamic world after being centuries under the colonialization of western countries. Especially here will be discussed on the ulama of Indonesia case.

In the nineteenth century, there were not ulama who had the good position on the national stage. There were only the local kyai. However, at that time happened the moving wave for going to pilgrimage. The Moslem people went to the holy place not only for a worship as the fulfillment of the five pillars of Islam, but many of them also learned the religious knowledge.

The title of hajj had the special prestige, even became the title such as degree based on the reached knowledge of them. One of the successful learners

${ }^{31}$ M. Dawam Rahardjo, Intelektual Inteligensia dan Perilaku Politik Bangsa: Risalah Cendekiawan Muslim (Bandung: Mizan, 1993), p. 186.

${ }^{32}$ Ahmad Najib Burhani, Islam dinamis: menggugat peran agama, membongkar doktrin yang membatu (Jakarta: Penerbit Buku Kompas, 2001), p. 135. 
from Indonesia was Syaikh Ahmad Khatib. He was the teacher of many popular people founding of the Islamic movement. Among them who successfully became the reformer were Syaikh Taher Jalaluddin, Syaikh Muhammad Jamil Jambek, Syaikh Sulaiman ar Rasuli, Dr. Haji Abdul Karim Amrullah and Dr. Haji Abdullah Ahmad. All of them were coming from Minang Island. ${ }^{33}$

In Java Island, Syaikh Ahmad Khatib had two great students, both were K.H. Ahmad Dahlan who was the founder of Muhammadiyah movement and K.H. Hasyim Asy'ari who was the founder of Tebu Ireng Pesantren and Nahdhatul Ulama (the Ulama Awakening). One again of his unforgettable student and his nephew was Haji Agus Salim who was the second person in Serikat Islam after Haji Oemar Said Cokroaminoto. ${ }^{34}$

Syaikh Ahmad Khatib, even though was not as the follower of reformatting concept of Muhammad Abduh line like his students, but he may be called as the Islamic reformer in Minangkabau. He did not prohibit his student reading the reformation publication such as Urwah al Wutsqa which appeared the radical writing written by Jamaluddin al-Afghani and Muhammad Abduh aiming they would against the new concept in spite of the contrary that happened. However, Minangkabau had become the birth of place of modernization..$^{35}$

The hajj and ulama raised the ethics and new culture as the preparation for the place of modernization movement. Actually, the modernization condition had been felt in early of this century. The condition which was strengthened by the ethical politic and awakening of national awareness mover by the educated people from Dutch schools. The ulama, hajj, and the preacher of Islamic local positively acted to directly response on education wave by the colonial through the awakening of Islamic knowledge from the Islamic centers. If the educated people from the Dutch schools studied in Dutch, there was also a wave to look for knowledge in the Islamic world, especially in the holy place.

After playing the important role in Indonesia independence, and especially in awakening the ummat consciousness, then in the course of time, the role of ulama in Indonesia begin to decline. The passing away of many great ulama44,

\footnotetext{
${ }^{33}$ Rahardjo, Intelektual Inteligensia dan Perilaku Politik Bangsa, 189.

${ }^{34} \mathrm{Ibid}$.

${ }^{35} \mathrm{Ibid}$.
}

JURNAL THEOLOGIA — Volume 28, Nomor 2, Desember 2017 
while there was the substitute of them come to bear. Right now, Moslem Indonesia felt the crisis of ulama. Whatever, after the falling down of Gus Dur from his position as president, meanwhile he always said as the representation of ulama, and also many ulama of NU supported him, but the respected of him was very little. This reality indicated that the role and the position of ulama especially in politic start to limit. The spirits of secularism that separate between the religion and the politic also play the main role in declining of the position of ulama in Indonesia.

Actually, this phenomenon is not in Indonesia only, but also in Islamic world commonly by the exception in Iran. Historically, as for John L. Esposito, the ulama served as advisers to rulers, enjoying royal patronage for their role as guardians of religion. While the vast majority of ulama today do not seek to rule, as they do in Ayatollah Khomeini's Iran, they continue to see themselves as the primary interpreters of Islam and a necessary part of any process of Islamization. However, in the twentieth century, secular as well as Islamic modernists and activists have challenged their role. Critics note that Islam knows no clergy and that the classical Islamic education of many ulama prepares them to respond creatively and effectively to modern realities. ${ }^{36}$

\section{The Role and the Position of Ulama in Urban Society}

As talking before that in the course of time, the world has changed. The change made new understanding of many issues. Among them, are urban society and the role and the position of ulama? We are sure that ulama can be separated with his ummat (society). Therefore, the role and the position of ulama are also coherent with the change of the society.

The evolution theory as for Compte, Spencer, or Sorokin may inspirit Steenbrink to write "Pesantren, Madrasah dan Sekolah". Even though the evolution is not a linear line but Steenbrink see that the Islamic Education of Indonesia goes toward school system. If it is correct, in fact, there is an influence on the social role of the ulama. Here will illustrate the change of social-culture related with ulama.

${ }^{36}$ John L Esposito, "Claiming the Center Political Islam in Transition," Vol. 19.2 (Cambridge: Harvard International Review, 1997), p. 8. 


\begin{tabular}{lllll} 
Society & Ulama & Communication & Role & Recruitment \\
\hline Pre-Industrial & Kyai & Oral & Social & Genealogies \\
Semi-Industrial & Teacher & Writing & Politic & Segmental \\
Industrial & Partner & Electronic & Intellectual & Sporadic \\
\hline
\end{tabular}

The scheme above must be read top-down to see his evolution and toward the right to see his interrelationship among each other. Because of this writing stresses on the ulama, so it will be read to the side and then to the bellow.

Really, the existence of ulama correlated to the communication form, the role of ulama in society, and the origin of recruitment. First, ulama stayed in Pesantren. There, they implanted their influence to the people around his pesantren. The close relation and personal with around with his pupil made Kyai became the charismatic person..$^{37}$ It can be understood because the ulama used the oral communication in the preaching of religion.

But the change has come. As written by Kuntowijoyo that in 1915 Ahmad Dahlan accompanied his students from Yogyakarta to Sriwedari, Surakarta. He also taught his male students in Kauman, Surakarta. Here, Dahlan acted more as teacher rather than a kyai. And then is 1915 appeared the translation of Qur'an in Javanese language in Suwara Muhammadiyah. Now started the new culture: the ulama wrote an article. If it before, there was a personal relationship between ulama and people, now by the existence of writing culture, the relation became impersonal. ${ }^{38}$

After the time the relation which first just impersonal start become abstract. Now, people only now that the ulama is still existed, but they are in everywhere. Someone will meet them if he is reading the newspaper, watching TV or listening to the Radio. For instance, Zainuddin MZ, heard by many people, but they do not know him but talk to him. Someone can hear him in privacy, without coming to the public life. When A.M. Fatwa and Abdul Qadir Jailani were imprisoned, nobody came to have a protest, a thing that never happens to K.H. Yusuf Hasyim, K.H. Sjansuri Badawi, or K.H. Alawy Muhammad. The ulama were not a respected teacher, but they have been a friend or a partner. Maybe someone

\footnotetext{
${ }^{37}$ Kuntowijoyo, Muslim tanpa Masjid: Esai-esai Agama, Budaya, dan Politik dalam Bingkai Strukturalisme Transendental (Bandung: Penerbit Mizan, 2001), p. 35.

${ }^{38}$ Ibid., p. 37.
}

JURNAL THEOLOGIA — Volume 28, Nomor 2, Desember 2017 
admires to Zainuddin MZ., but the people's admiration, not more than to Rhoma Irama, Westlife or Zidane. That is the abstract admiration. Ulama may come from everywhere and whoever. Ulama may come from non-santri. In another word that the ulama are coming from here and there sporadically. The ulama are not social category, but intellectual category.

In industrial society the ulama as kyai and a teacher will be gone, but not for the ulama as a partner. There is no distinction between ulama and non-ulama, between the religious expert and natural expert, all have the place. So what we need now is the ulama in intellectual category.

\section{E. Conclusion}

On the basis of preceding analysis, here will be formulated two conclusions, namely: First, The urban society is the real phenomena that came together with the industrial society. The urban society has the similar characteristics of the industrial one. As city dwellers composed of the whole mass of people, the massification process occurred within formerly intact communities does not emerge, the community will fall apart, which is the distinctive quality of urban society. Urban dwellers tend to lose the desire for a community, the desire for engagement and the desire for dependence.

Secondly, as the impact of the industrial society, the role and the position of ulama in Indonesian urban society since the 19th up to 21st century have change. In the 19th century, which was the pre-industrial society age, ulama is a Kyai, the role of ulama was found in any kinds of social life fields. Ulama was born, and between ulama and people used the oral communication that there was the very close relationship between them. And this all change in the coming of semi-industrial around the 20th century. Here, ulama became a teacher, and among ulama and his people start to use the writing communication as well as the oral one, ulama in this era also has participated in a politic field that araised the segmentation of ulama. The coming of millennium era or in industrial society, the role of ulama more in the intellectual field. Ulama became abstract and the people know the ulama through the mass media. Ulama in this age became a partner of his people and then ulama came sporadically, it means that everybody may be an ulama in this era wherever he comes as long as he is a Moslem and he has the capability of knowledge in the religious field. [ 


\section{BIBLIOGRAPHY}

Abidin, M. Zainal. "Positioning of Islamic Philosophy as the Basis of Establishment of Integralistic View of Science (Reposisi Filsafat Islam Sebagai Basis Pengembangan Ilmu Integralistik)." In IC-THUSI, p. 1-20. Jakarta: Sadra International Institute, 2014.

Abidin, Muhammad Zainal. "Dinamika Perkembangan Ilmu dalam Islam Serta Statusnya dalam Perkembangan Peradaban Modern." Jurnal Ilmu Ushuluddin 11, no. 1 (2012): p. 21-42.

- - Paradigma Islam dalam Pembangunan Ilmu Integralistik: Membaca Pemikiran Kuntowijoyo. Banjarmasin: IAIN Antasari Press, 2016.

Ahmad Najib Burhani. Islam dinamis: Menggugat Peran Agama, Membongkar Doktrin yang Membatu. Jakarta: Penerbit Buku Kompas, 2001.

Bakhash, Shaul. The Reign of the Ayatollahs: Iran and the Islamic Revolution. Basic Books, 1984.

Bruinessen, Martin van, and Julia Day Howell. Sufism and the "Modern" in Islam. London; New York; New York: I.B. Tauris, 2007.

Dewan Redaksi Ensiklopedi Islam. Ensiklopedi Islam. Jakarta: PT Ichtiar Baru Van Hoeve, 1994.

Esposito, John L. "Claiming the Center Political Islam in Transition," 19.2:8. Cambridge: Harvard International Review, 1997.

- _ . The Oxford Encyclopedia of the Modern Islamic World. New York [etc: Oxford University Press, 1995.

Horikoshi, Hiroko. Kyai dan Perubahan Sosial. Translated by Umar Basalim and Andi Muarly Sunrawa. Jakarta: Perhimpunan Pengembangan Pesantren dan Masyarakat, 1987.

Jary, David, and Julia Jary. Collins Dictionary of Sociology. Glasgow [Scotland: Collins, 2012. http://www.credoreference.com/book/collinssoc.

Kuntowijoyo. Muslim tanpa Masjid: Esai-esai Agama, Budaya, dan Politik dalam Bingkai Strukturalisme Transendental. Bandung: Penerbit Mizan, 2001. 
Kuntowijoyo, Kuntowijoyo. "Between Mosque and Market: The Muslim Community in Quiapo, Metro Manila." Studia Islamika 1, No. 3 (1994). https://doi.org/10.15408/sdi.v1i3.849.

Kuper, Adam. The Social Science Encyclopedia. Routledge, 2004.

Majid, Nurcholish. Islam: Kemodernan dan Keindonesiaan. Bandung: Mizan, 1998.

Mujiburrahman, M. Zainal Abidin, and Rahmadi. Ulama Kharismatik di Tanah Banjar: Potret Guru Danau, Guru Bachiet, dan Guru Zuhdi. Kurnia Kalam Semesta, 2016.

Mujiburrahman, Mujiburrahman, M. Zainal Abidin, and Rahmadi Rahmadi. "Ulama Banjar Kharismatik Masa Kini di Kalimantan Selatan: Studi terhadap Figur Guru Bachiet, Guru Danau, dan Guru Zuhdi." Al Banjari 11, no. 2 (2012): 107-137.

O'Connor, Richard A. A Theory of Indigenous Southeast Asian Urbanism. Singapore: Institute of Southeast Asian Studies (ISEAS), ASEAN Economic Research Unit, 1983.

Rahardjo, M. Dawam. Intelektual Inteligensia dan Perilaku Politik Bangsa: Risalah Cendekiawan Muslim. Bandung: Penerbit Mizan, 1993.

Simon, Reeva S, Philip Mattar, and Richard W Bulliet. Encyclopedia of the Modern Middle East. New York [N.Y.]: Macmillan Library Reference USA: Simon \& Schuster Macmillan; Simon \& Schuster and Prentice Hall International, 1996.

Von der Mehden, Fred R. Religion and Modernization in Southeast Asia. Syracuse, N.Y.: Syracuse University Press, 1986.

Zayid, Mahmud Y. The Quran Dar: An English Translation of the Meaning of the Quran. Beirut: Dar al-Choura, 1980. 